\title{
Copper complexes with bibracchial lariat ethers: from mono- to binuclear structures
}

\author{
Covadonga Rodríguez-Infante a , David Esteban a, Fernando Avecilla ${ }^{\text {a }}$, \\ Andrés de Blas ${ }^{\mathrm{a}, * 1}$, Teresa Rodríguez-Blas ${ }^{\mathrm{a}, * 2}$, Jose Mahía ${ }^{\mathrm{b}}$, Anjos L. Macedo ${ }^{\mathrm{c}}$, \\ Carlos F.G.C. Geraldes ${ }^{\mathrm{d}}$ \\ a Departamento de Química Fundamental, Facultad de Ciencias, Universidade da Coruña, Campus da Zapateira s/n 15071 A Coruña, Spain \\ ${ }^{\mathrm{b}}$ Servicios Xerais de Apoio á Investigación, Universidade da Coruña, Campus da Zapateira s/n 15071 La Coruña, Spain \\ ${ }^{\mathrm{c}}$ Departamento de Quimica, C.Q.F.B., Faculdade de Ciências e Tecnologia, Universidade Nova de Lisboa, 2825-114 Caparica, Portugal \\ d Departamento de Bioquímica, Faculdade de Ciências e Tecnologia, e Centro de Neurociências, Universidade de Coimbra, Apartado 3126, \\ P-3049 Coimbra, Portugal
}

Received 31 October 2000; accepted 14 February 2001

\begin{abstract}
Copper(II) complexes with a series of bibracchial lariat ethers are described. Independently of the nature of the counterion present (nitrate or perchlorate), the lariat ether $N, N^{\prime}$-bis(2-aminobenzyl)-1,10-diaza-15-crown-5 $\left(\mathbf{L}^{1}\right)$ always forms mononuclear complexes, whereas the lariat ethers $N, N^{\prime}$-bis(2-aminobenzyl)-4,13-diaza-18-crown-6 (L $\left.{ }^{2}\right)$ and $N, N^{\prime}$-bis(2-salicylaldiminobenzyl)4,13-diaza-18-crown-6 $\left(\mathbf{L}^{3}\right)$ only give binuclear compounds. The X-ray crystal structure of $\left[\mathrm{CuL}^{1}\right]\left(\mathrm{ClO}_{4}\right)_{2}$ shows a seven-coordinated copper(II) ion in a distorted (axially compressed) pentagonal-bipyramidal geometry. The X-ray crystal structure of $\left[\mathrm{Cu}_{2}\left(\mathbf{L}^{3}-2 \mathrm{H}\right)\right]\left(\mathrm{ClO}_{4}\right)_{2}$ confirms the binuclear nature of the compound with both metal ions having identical coordination environments and each one placed out of the crown hole but efficiently encapsulated by the corresponding pendant arm; each copper(II) ion is five-coordinated with an intermediate geometry between trigonal-bipyramidal and square-pyramidal $(\tau=0.40)$. The EPR spectra in frozen solution samples are in accordance with a stable coordinate pattern for the metal centre of ligand $\mathbf{L}^{1}$, yielding a rhombic distorted complex with axial compression in solution, in agreement with the X-ray crystal structure of $\left[\mathrm{CuL}^{1}\right]\left(\mathrm{ClO}_{4}\right)_{2}$. For the binuclear complexes of $\mathbf{L}^{2}$ and $\mathbf{L}^{3}$, the $\mathrm{Cu}(\mathrm{II})$ centres in solution can be distorted from their tetragonally elongated structures via interaction with ethanol and/or the nitrate counterion, leading to more than one species. (C) 2001 Elsevier Science B.V. All rights reserved.
\end{abstract}

Keywords: Copper(II) complexes; Macrocycle; Lariat ether; Crystal structures; EPR spectroscopy

\section{Introduction}

Over the last few years, increasing attention has been focused on the role of lariat ethers, bracchial crown compounds, as metal complexing agents [1,2]. These compounds constitute a sub-class of macrocyclic polyethers and are characterised by the presence of one (monobracchial), or more (polybracchial), side arms attached to pivotal atoms on the parent macrocyclic

\footnotetext{
1 *Corresponding author: Tel.: +34-981-167000; fax: + 34-981167065; e-mail: mayter@udc.es.

2 *Corresponding author: Tel.: + 34-981-167000; fax: + 34-981167065 .
}

ring. As such these compounds may be regarded as having a structural character intermediate to that of a flexible macrocyclic polyether and a relatively rigid macrobicyclic cage or cryptand. The presence of additional donor atoms in the side arms can be used to enhance the coordination potential of these polybracchial ligands and/or to build polynuclear structures.

This paper describes the synthesis, structure and spectral properties of copper(II) complexes with the bibracchial lariat ethers shown in Chart $1 . \mathbf{L}^{1}$ and $\mathbf{L}^{2}$ may act as $\mathrm{N}_{4} \mathrm{O}_{3}$ and $\mathrm{N}_{4} \mathrm{O}_{4}$ donor ligands, respectively. $\mathbf{L}^{3}$ is a potentially $\mathrm{N}_{4} \mathrm{O}_{6}$ donor macrocyclic receptor which possesses two phenolic groups that can be deprotonated leading to the di-anionic ligand. Structurally, 
$\mathbf{L}^{2}$ derives from $\mathbf{L}^{1}$ by incorporation of a $-\mathrm{CH}_{2}-\mathrm{O}-$ $\mathrm{CH}_{2}-$ fragment into its backbone whereas $\mathbf{L}^{3}$ comes from $\mathbf{L}^{2}$ by condensation with salicylaldehyde. These three macrocycles have been designed in order to get not only mono but also polynuclear structures with transition metal ions.

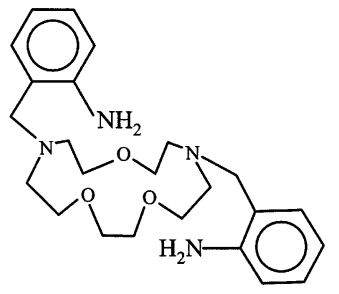

$\mathrm{L}^{1}$

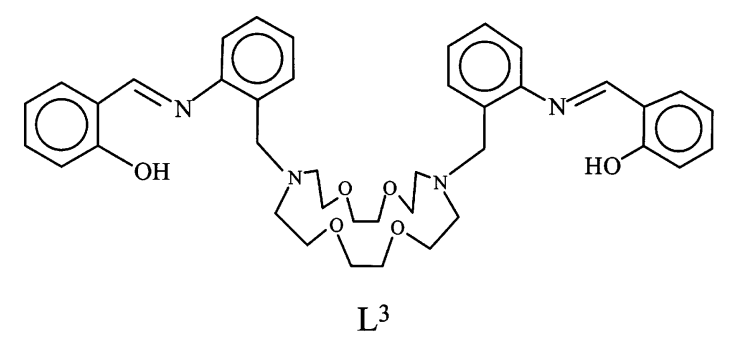

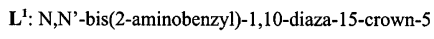

$\mathbf{L}^{2}$ : N,N'-bis(2-aminobenzyl)-4,13-diaza-18-crown-6

$\mathbf{L}^{3}$ : N,N'-bis(2-salicylaldiminobenzyl)-4,13-diaza-18-crown-6

Chart 1.

$\mathrm{L}^{2}$

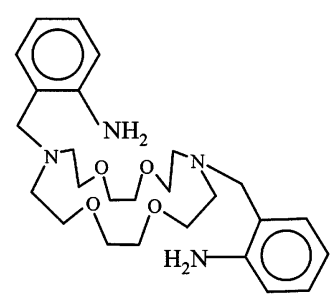

\section{Experimental}

\subsection{Reagents}

$N, N^{\prime}$-bis(2-nitrobenzyl)-4,13-diaza-18-crown-6 was synthesised according to the literature method [3]. All other chemicals were purchased from commercial sources and used without further purification. Solvents were of reagent grade purified by the usual methods.

Caution: although we have experienced no difficulties with the perchlorate salts, these should be regarded as potentially explosive and handled with care.

\subsection{Preparation of the ligands}

The bibracchial lariat ether $N, N^{\prime}$-bis(2-aminobenzyl)1,10-diaza-15-crown-5 $\left(\mathbf{L}^{1}\right)$ was prepared as described previously by us [4].

\subsection{1. $N, N^{\prime}$-bis(2-aminobenzyl)-4,13-diaza-18-crown-6 $\left(\boldsymbol{L}^{2}\right)$}

$N, N^{\prime}$-bis-(2-nitrobenzyl)-4,13-diaza-18-crown-6 $(1.745 \mathrm{~g}, 3.3 \mathrm{mmol})$ was dissolved in absolute ethanol $(50 \mathrm{ml})$ and $\mathrm{Pd} / \mathrm{C}$ was added. Hydrazine hydrate $(7 \mathrm{ml})$ was slowly added and the reaction mixture was heated and stirred for $24 \mathrm{~h}$. It was then filtered and the solvent was removed from the filtrate in a rotary evaporator. Addition of cold diethyl ether to the oily residue led to the deposition of a white precipitate. Yield: $0.9 \mathrm{~g}(60 \%)$; m.p. $120-121^{\circ} \mathrm{C}$. Anal. Calc. for $\mathrm{C}_{26} \mathrm{H}_{40} \mathrm{~N}_{4} \mathrm{O}_{4} \cdot 3 \mathrm{H}_{2} \mathrm{O}$ : C, 59.3; H, 8.8; N, 10.6. Found: C, 59.6; H, 8.6; N, 10.5\%. ${ }^{1} \mathrm{H}$ NMR $\left(200 \mathrm{MHz}, \mathrm{CDCl}_{3}\right) ; \delta=7.03(\mathrm{~m}, 4 \mathrm{H}, \operatorname{arH})$, $6.60(\mathrm{~m}, 4 \mathrm{H}, \operatorname{arH}), 3.74\left(\mathrm{~s}, 4 \mathrm{H}, \mathrm{N}-\mathrm{CH}_{2}-\right.$ ar $), 3.63(\mathrm{t}$, $\left.8 \mathrm{H},-\mathrm{CH}_{2} \mathrm{O}-\right), 3.54\left(\mathrm{~s}, 8 \mathrm{H},-\mathrm{CH}_{2}-\mathrm{O}-\right), 2.81(\mathrm{t}, 8 \mathrm{H}$, $\left.\mathrm{N}-\mathrm{CH}_{2}-\right)$. ${ }^{13} \mathrm{C}$ NMR $\left(200 \mathrm{Mz}, \mathrm{CDCl}_{3}\right) ; \delta=148.00$, $130.46,128.38,123.08,117.61,116.06,70.47,69.19$, 58.67, 54.99. FAB-MS: $m / z=472\left[\mathbf{L}^{1}+1\right]$; IR $(\mathrm{KBr}$ discs): 3400, $3300 v\left(\mathrm{NH}_{2}\right), 1618 \delta\left(\mathrm{NH}_{2}\right), 1583,1496$ $v(\mathrm{C}=\mathrm{C}), 1458 \delta\left(\mathrm{CH}_{2}\right) \mathrm{cm}^{-1}$.

\subsection{2. $N, N^{\prime}$-bis(2-salicylaldiminobenzyl)- \\ 4,13-diaza-18-crown-6 $\left(\boldsymbol{L}^{3}\right)$}

Addition of salicylaldehyde $(0.052 \mathrm{~g}, 0.4 \mathrm{mmol})$ to a stirred ethanolic solution of $\mathrm{L}^{2} \cdot 3 \mathrm{H}_{2} \mathrm{O}(0.105 \mathrm{~g}, 0.2$ $\mathrm{mmol}$ ) gave a yellow solution which was refluxed for 2 $\mathrm{h}$. Evaporation of the solution in vacuo gave a deep yellow oil which was precipitated by addition of diethyl ether:hexane (1:1). The solid was filtered off and dried over $\mathrm{CaCl}_{2}$. Yield: 0.080 g $(55 \%)$; m.p. $100-101^{\circ} \mathrm{C}$. Anal. Calc. for $\mathrm{C}_{40} \mathrm{H}_{48} \mathrm{~N}_{4} \mathrm{O}_{6}: \mathrm{C}, 70.6 ; \mathrm{H}, 7.1 ; \mathrm{N}, 8.2$. Found: C, 70.0; H, 7.0; N, 8.1\%. ${ }^{1} \mathrm{H}$ NMR $(200 \mathrm{MHz}$, $\left.\mathrm{CD}_{3} \mathrm{CN}\right) ; \delta=13.21 \quad(\mathrm{~s}, 2 \mathrm{H},-\mathrm{OH}), 8.67 \quad(\mathrm{~s}, 2 \mathrm{H}$, $-\mathrm{CH}=\mathrm{N}-), 6.9,7.6(\mathrm{~m}, 8 \mathrm{H},-\mathrm{arH}), 3.77(\mathrm{~s}, 4 \mathrm{H}, \mathrm{ar}-$ $\left.\mathrm{CH}_{2}-\mathrm{N}-\right), 3.49$ (t, 8H, $\left.-\mathrm{CH}_{2}-\mathrm{O}-\right), 3.42(\mathrm{~s}, 8 \mathrm{H},-\mathrm{O}-$ $\mathrm{CH}_{2}-$ ), $2.73\left(\mathrm{t}, 8 \mathrm{H},-\mathrm{N}-\mathrm{CH}_{2}-\right.$ ). UV-Vis (acetonitrile) 229, 262, $334 \mathrm{~nm}$. FAB-MS: $m / z=681\left[\mathrm{~L}^{3}+1\right]$. IR $(\mathrm{KBr}$ discs $): 1618 v(\mathrm{C}=\mathrm{N}), 1573,1483 v(\mathrm{C}=\mathrm{C}), 1454$ $\delta\left(\mathrm{CH}_{2}\right) \mathrm{cm}^{-1}$.

\subsection{Preparation of the copper complexes}

\subsection{1. $\left[\mathrm{CuL}^{1}\right]\left(\mathrm{ClO}_{4}\right)_{2}(\mathbf{1})$}

To a solution of $\mathrm{L}^{1}(0.114 \mathrm{~g}, 0.26 \mathrm{mmol})$ in absolute ethanol $(10 \mathrm{ml})$ was added with stirring a solution of $\mathrm{Cu}\left(\mathrm{ClO}_{4}\right)_{2} \cdot 6 \mathrm{H}_{2} \mathrm{O}(0.197 \mathrm{~g}, 0.52 \mathrm{mmol})$ in absolute ethanol $(5 \mathrm{ml})$. The green solution was stirred under reflux for $2 \mathrm{~h}$. The green precipitate formed was filtered off and air dried. Yield: $0.142 \mathrm{~g}(77 \%)$. X-ray quality crystals were grown by recrystallisation of $\mathbf{1}$ in absolute ethanol. Anal. Calc. for $\mathrm{C}_{24} \mathrm{H}_{36} \mathrm{~N}_{4} \mathrm{O}_{11} \mathrm{CuCl}_{2}: \mathrm{C}, 41.7 ; \mathrm{H}$, 5.2; N, 8.1. Found: C, 41.8; H, 5.2; N, 8.2\%. UV-Vis (acetonitrile) $795 \mathrm{~nm}$. FAB-MS: $m / z=492\left(\mathbf{1}-2 \mathrm{ClO}_{4}\right)$. IR (KBr discs): $3420 v\left(\mathrm{NH}_{2}\right), 1618 \delta\left(\mathrm{NH}_{2}\right), 1587,1500$ $v(\mathrm{C}=\mathrm{C}), 1462 \delta\left(\mathrm{CH}_{2}\right), 1088,625\left(\mathrm{ClO}_{4}\right) \mathrm{cm}^{-1}$.

\subsection{2. $\left[\mathrm{CuL}^{1}\right]\left(\mathrm{NO}_{3}\right)_{2}(2)$}

To a solution of $\mathrm{L}^{1}(0.114 \mathrm{~g}, 0.26 \mathrm{mmol})$ in absolute ethanol $(10 \mathrm{ml})$ was added with stirring a solution of $\mathrm{Cu}\left(\mathrm{NO}_{3}\right)_{3} \cdot 3 \mathrm{H}_{2} \mathrm{O}(0.128 \mathrm{~g}, 0.53 \mathrm{mmol})$ in absolute ethanol $(7 \mathrm{ml})$. The deep green solution was stirred under reflux for $2 \mathrm{~h}$. The green solid 2 was recovered by 
filtration after the solution was half evaporated in vacuo and diethyl ether $(3 \mathrm{~mL})$ was added. Yield: 0.058 g $(70 \%)$. Anal. Calc. for $\mathrm{C}_{24} \mathrm{H}_{36} \mathrm{~N}_{6} \mathrm{O}_{9} \mathrm{Cu}: \mathrm{C}, 46.8 ; \mathrm{H}, 5.9$; $\mathrm{N}, 13.6$. Found: $\mathrm{C}, 46.2 ; \mathrm{H}, 5.7 ; \mathrm{N}, 13.2 \%$. UV-Vis (acetonitrile) $750 \mathrm{~nm}$. FAB-MS: $m / z=492\left(2-2 \mathrm{NO}_{3}\right)$. IR ( $\mathrm{KBr}$ discs): $3420 \quad v\left(\mathrm{NH}_{2}\right), 1618 \quad \delta\left(\mathrm{NH}_{2}\right), 1591$ $v(\mathrm{C}=\mathrm{C}), 1458 \delta\left(\mathrm{CH}_{2}\right), 1380\left(\mathrm{NO}_{3}\right) \mathrm{cm}^{-1}$.

\subsection{3. $\left[\mathrm{Cu}_{2} \mathrm{~L}^{2}\right]\left(\mathrm{ClO}_{4}\right)_{4}(\mathbf{3})$}

To a solution of $\mathrm{L}^{2} \cdot 3 \mathrm{H}_{2} \mathrm{O}(0.130 \mathrm{~g}, 0.25 \mathrm{mmol})$ in absolute ethanol $(15 \mathrm{ml})$ was added with stirring a solution of $\mathrm{Cu}\left(\mathrm{ClO}_{4}\right)_{2} \cdot 6 \mathrm{H}_{2} \mathrm{O}(0.188 \mathrm{~g}, 0.50 \mathrm{mmol})$ in absolute ethanol $(5 \mathrm{ml})$. The green solution was stirred under reflux for $1 \mathrm{~h}$. The green precipitate formed was filtered off and air dried. Yield: $0.178 \mathrm{~g}(71 \%)$. Anal. Calc. for $\mathrm{C}_{26} \mathrm{H}_{40} \mathrm{~N}_{4} \mathrm{O}_{12} \mathrm{CuCl}_{2}$ : C, 31.3; $\mathrm{H}, 4.0 ; \mathrm{N}$, 5.6. Found: $\mathrm{C}, 31.6 ; \mathrm{H}, 3.7 ; \mathrm{N}, 5.6 \%$. UV-Vis (acetonitrile) $750 \mathrm{~nm}$. FAB-MS: $m / z=538\left[\mathrm{CuL}^{2}\right]^{+}$. IR ( $\mathrm{KBr}$ discs): $3447 v\left(\mathrm{NH}_{2}\right), 1616 \delta\left(\mathrm{NH}_{2}\right), 1585,1497 v(\mathrm{C}=\mathrm{C}), 1460$ $\delta\left(\mathrm{CH}_{2}\right), 1117,627\left(\mathrm{ClO}_{4}\right) \mathrm{cm}^{-1}$.

\subsection{4. $\left[\mathrm{Cu}_{2} \mathrm{~L}^{2}\right]\left(\mathrm{NO}_{3}\right)_{4} \cdot 2 \mathrm{EtOH}$ (4)}

To a solution of $\mathrm{L}^{2} \cdot 3 \mathrm{H}_{2} \mathrm{O}(0.130 \mathrm{~g}, 0.25 \mathrm{mmol})$ in absolute ethanol $(15 \mathrm{ml})$ was added with stirring a solution of $\mathrm{Cu}\left(\mathrm{NO}_{3}\right)_{2} \cdot 3 \mathrm{H}_{2} \mathrm{O}(0.122 \mathrm{~g}, 0.50 \mathrm{mmol})$ in absolute ethanol $(15 \mathrm{ml})$. The green solution was stirred under reflux for $1 \mathrm{~h}$. Upon cooling the filtrate to room temperature (r.t.), green crystals formed, which were collected by filtration. Yield: $0.037 \mathrm{~g}(20 \%)$. Anal. Calc. for $\mathrm{C}_{26} \mathrm{H}_{40} \mathrm{~N}_{6} \mathrm{O}_{10} \mathrm{Cu} \cdot 2 \mathrm{EtOH}$ : C, 38.3; H, 5.6; N, 11.9 . Found: C, 38.0; H, 5.4; N, 11.9\%. UV-Vis (acetonitrile) $680 \mathrm{~nm}$. FAB-MS: $m / z=473\left[\mathbf{L}^{2}+\mathrm{H}\right]^{+}$. IR $(\mathrm{KBr}$ discs): $3433 v\left(\mathrm{NH}_{2}\right), 1616 \delta\left(\mathrm{NH}_{2}\right), 1589,1495 v(\mathrm{C}=\mathrm{C})$, $1475,1384,1288\left(\mathrm{NO}_{3}\right) \mathrm{cm}^{-1}$.

\subsection{5. $\left[\mathrm{Cu}_{2}\left(\mathrm{~L}^{3}-2 \mathrm{H}\right)\right]\left(\mathrm{ClO}_{4}\right)_{2} \cdot \mathrm{H}_{2} \mathrm{O}$ (5)}

Salicylaldehyde $(0.052 \mathrm{~g} ; 0.43 \mathrm{mmol})$ was added to a solution of $\mathrm{L}^{2} \cdot 3 \mathrm{H}_{2} \mathrm{O}(0.110 \mathrm{~g} ; 0.21 \mathrm{mmol})$ in isopropanol $(20 \mathrm{ml})$. After the resulting solution was refluxed and heated for $2 \mathrm{~h}$, triethylamine $(0.060 \mathrm{ml}$; $0.43 \mathrm{mmol}$ ) was added and the new solution refluxed for $30 \mathrm{~min} . \mathrm{Cu}\left(\mathrm{ClO}_{4}\right)_{2} \cdot 6 \mathrm{H}_{2} \mathrm{O}(0.158 \mathrm{~g}, 0.43 \mathrm{mmol})$ was then added and the green mixture refluxed and stirred for $1 \mathrm{~h}$. The green precipitate formed was filtered off and dried. Yield: $0.185 \mathrm{~g}(85 \%)$. X-ray quality crystals were grown by recrystallisation from $\mathrm{CH}_{3} \mathrm{CN}$. Anal. Calc. for $\mathrm{C}_{40} \mathrm{H}_{46} \mathrm{~N}_{4} \mathrm{O}_{14} \mathrm{CuCl}_{2} \cdot \mathrm{H}_{2} \mathrm{O}: \mathrm{C}, 46.9 ; \mathrm{H}, 4.7 ; \mathrm{N}$, 5.5. Found: $\mathrm{C}, 46.5 ; \mathrm{H}, 4.6$; N, 5.6\%. UV-Vis (acetonitrile) $215,239,290,400,625 \mathrm{~nm}$. FAB-MS: $m / z=905$ $\left(5-\mathrm{ClO}_{4}\right), 806 \quad\left(5-2 \mathrm{ClO}_{4}\right)$. IR ( $\mathrm{KBr}$ discs): 1608 $v(\mathrm{C}=\mathrm{N}), 1578,1531,1490 v(\mathrm{C}=\mathrm{C}), 1462,1438 \delta\left(\mathrm{CH}_{2}\right)$, $1100,625\left(\mathrm{ClO}_{4}\right) \mathrm{cm}^{-1}$.

\subsection{6. $\left[\mathrm{Cu}_{2}\left(\mathrm{~L}^{3}-2 \mathrm{H}\right)\right]\left(\mathrm{NO}_{3}\right)_{2} \cdot \mathrm{H}_{2} \mathrm{O}(6)$}

The deep green complex was prepared as described for 5 by using $\mathrm{Cu}\left(\mathrm{NO}_{3}\right)_{2} \cdot 3 \mathrm{H}_{2} \mathrm{O}(0.103 \mathrm{~g} ; 0.43 \mathrm{mmol})$.
Yield: 0.172 g $(85 \%)$ Anal. Calc. for $\mathrm{C}_{40} \mathrm{H}_{46} \mathrm{~N}_{6} \mathrm{O}_{12} \mathrm{Cu} \cdot \mathrm{H}_{2} \mathrm{O}: \mathrm{C}, 50.7 ; \mathrm{H}, 5.1 ; \mathrm{N}, 8.9$. Found: C, 50.8; H, 4.9; N, 8.9\%. UV-Vis (acetonitrile) 218, 238, 290, 400, $635 \mathrm{~nm}$. FAB-MS: $m / z=868\left(6-\mathrm{NO}_{3}\right)$, $806\left(6-2 \mathrm{NO}_{3}\right)$. IR ( $\mathrm{KBr}$ discs $): 1608 v(\mathrm{C}=\mathrm{N}), 1579$, $1529,1489 v(\mathrm{C}=\mathrm{C}), 1464,1437 \delta\left(\mathrm{CH}_{2}\right), 1384\left(\mathrm{NO}_{3}\right)$ $\mathrm{cm}^{-1}$.

\subsection{Measurements}

Elemental analysis, ${ }^{1} \mathrm{H}$ NMR, IR and FAB mass spectra were carried out by Servicios Xerais de Apoio a Investigación of the Universidade da Coruña. Elemental analyses were carried out on a Carlo Erba 1180 elemental analyser. FAB mass spectra were recorded on a Fisions Quatro mass spectrometer with a $\mathrm{Cs}$ ion gun using 3-nitrobenzyl alcohol as matrix. ${ }^{1} \mathrm{H}$ and ${ }^{13} \mathrm{C}$ NMR spectra were run on a Bruker AC 200F using acetonitrile- $\mathrm{d}_{3}$ as solvent. IR spectra were recorded, as $\mathrm{KBr}$ discs, using a Bruker Vextor 22. UV-Vis spectra were run on a Uvikon 942 Plus spectrophotometer. Melting points were measured on a Gallenkamp instrument. Conductivity measurements were carried out with a Crison Micro CM 2201 conductivimeter using approximately $10^{-3} \mathrm{M}$ solutions of the complexes in acetonitrile or dimethylformamide.

The EPR spectra (X-band, 0.34 T, 9.5 GHz), were obtained in a continuous wave Bruker EMX spectrometer, equipped with a continuous flow Oxford Instruments cryostat for low temperature measurements. The EPR experiments were performed at a microwave power of $2 \mathrm{~mW}$, a modulation frequency of $100 \mathrm{kHz}$ and temperatures of 77 and $40 \mathrm{~K}$ using $0.5 \mathrm{mM}$ solutions of the $\mathrm{Cu}$ (II) complexes dissolved either on ethanol or acetonitrile. In order to obtain the anisotropic EPR parameters, simulation of the experimental spectra were performed using SimFonia v.1.2 (Bruker Instruments Inc. software). The simulation was carried out ignoring the isotopic mixture of the copper nuclei and nuclear quadrupole effects.

\subsection{X-ray crystallography}

Green blocklike crystals of compounds $\mathbf{1}$ and $\mathbf{5}$ (dimensions: $0.85 \times 0.65 \times 0.20 \mathrm{~mm}^{3}$ for $\mathbf{1}$ and $0.35 \times$ $0.30 \times 0.15 \mathrm{~mm}^{3}$ for 5) were used for the structure determination. Selected crystallographic data appear in Table 1. Three dimensional X-ray data were collected at r.t. in the range $2.59<2 \theta<33.17^{\circ}$ for 1 and $2.02<$ $2 \theta<28.24^{\circ}$ for $\mathbf{5}$, on a Siemens SMART 1000 CCD diffractometer with graphite monochromated Mo $\mathrm{K} \alpha$ radiation $(\lambda=0.71073 \AA$ ) by the $\Omega$-scan method. Complex scattering factors were taken from the program package SHELXTL [5] as implemented on an Intel Pentium $^{\circledR}$ III computer. The structure was solved by direct methods and refined by full-matrix least-squares meth- 
ods on $F^{2}$. A total of 25022 reflections were measured for $\mathbf{1}$ and 13196 for $\mathbf{5}$, all of which were processed and corrected for Lorentz and polarization effects and for absorption by semi-empirical method based on symmetry-equivalent and repeated reflections (minimum and maximum transmission coefficients 0.6092 and 1.0000 for 1, 0.6775 and 0.8398 for 5); 6957 and 2815 independent reflections exceeded, respectively, the significance level $|F| / \sigma(|F|)>4$. Hydrogen atoms were included in calculated positions and refined in riding mode. For $\mathbf{1}$ convergence was reached at a final $R=0.0590, w R_{2}=$ $0.1400,395$ parameters for all unique 10506 data with allowance for thermal anisotropy of all non-hydrogen atoms. Minimum and maximum final electron density: -0.592 and 0.661 e $\AA^{-3}$. For 5 convergence was reached at a final $R=0.0750, w R_{2}=0.2012, \quad 280$ parameters for all unique 5167 data with allowance for thermal anisotropy of all non-hydrogen atoms. Minimum and maximum final electron density: -0.573 and 0.598 e $\AA^{-3}$.

\section{Results and discussion}

\subsection{Copper complexes with $\boldsymbol{L}^{1}$ and $\boldsymbol{L}^{2}$}

The reaction of the bibracchial lariat ethers $N, N^{\prime}-$ bis(2-aminobenzyl)-1,10-diaza-15-crown-5 $\left(\mathbf{L}^{1}\right)$ and $N, N^{\prime}$-bis(2-aminobenzyl)-4,13-diaza-18-crown-6 $\left(\mathbf{L}^{2}\right)$ with copper(II) salts (perchlorate or nitrate) in absolute ethanol gives green products with formulas $\left[\mathrm{CuL}^{1}\right](\mathrm{X})_{2}$ $\left(\mathrm{X}=\mathrm{ClO}_{4}^{-}, \quad \mathbf{1} ; \mathrm{NO}_{3}^{-}, 2\right)$ and $\left[\mathrm{Cu}_{2} \mathbf{L}^{2}\right](\mathrm{X})_{4} \quad(\mathrm{X}=$ $\left.\mathrm{ClO}_{4}{ }^{-}, 3 ; \mathrm{NO}_{3}{ }^{-}, 4\right)$. The elemental analysis indicates

Table 1

Crystallographic data for complexes $\mathbf{1}$ and $\mathbf{5}$

\begin{tabular}{lll}
\hline & Complex 1 & Complex 5 \\
\hline Empirical formula & $\mathrm{C}_{24} \mathrm{H}_{36} \mathrm{~N}_{4} \mathrm{O}_{11} \mathrm{Cl}_{2} \mathrm{Cu}$ & $\mathrm{C}_{40} \mathrm{H}_{48} \mathrm{~N}_{4} \mathrm{O}_{14} \mathrm{Cl}_{2} \mathrm{Cu}_{2}$ \\
FW & 691.01 & 1006.80 \\
Crystal system & monoclinic & monoclinic \\
Space group & $P 2_{1} / c$ & $P 2_{1} / n$ \\
Unit cell dimensions & & \\
$\quad a(\AA)$ & $18.0710(9)$ & $13.2905(3)$ \\
$b(\AA)$ & $12.7846(6)$ & $11.5652(4)$ \\
$c(\AA)$ & $12.3269(6)$ & $13.8251(4)$ \\
$\beta\left({ }^{\circ}\right)$ & $92.4920(10)$ & $96.2910(10)$ \\
$V\left(\AA^{3}\right)$ & $2845.2(2)$ & $2112.22(11)$ \\
$Z$ & 4 & 2 \\
$T(\mathrm{~K})$ & $298(2)$ & $298(2)$ \\
$D_{\text {calc }}(\mathrm{g}$ cm & & 1.583 \\
$F(000)$ & 1.613 & 1040 \\
Final $R$ indices & 1436 & $R_{1}=0.0750$, \\
$\quad I>2 \sigma(I)]^{\mathrm{a}}$ & $R_{1}=0.0590$, & $w R_{2}=0.1657$ \\
Final $R$ indices (for all & $R_{1}=0.0986$, & $R_{1}=0.1442$, \\
$\quad$ data) & $w R_{2}=0.1230$ & $w R_{2}=0.2012$ \\
\hline
\end{tabular}

${ }^{\mathrm{a}} R_{1}=\Sigma|| F_{\mathrm{o}}|-| F_{\mathrm{c}}|| \Sigma\left|F_{\mathrm{o}}\right|, w R_{2}=\left\{\Sigma\left[w\left(\left.|| F_{\mathrm{o}}\right|^{2}-\left|F_{\mathrm{c}}\right|^{2} \mid\right)^{2}\right] / \Sigma\left[w\left(F_{\mathrm{o}}^{4}\right)\right]\right\}^{1 / 2}$. that compound $\mathbf{4}$ crystallises with two molecules of ethanol. The four complexes are air stable. Attempts to prepare binuclear complexes with $\mathbf{L}^{1}$ and mononuclear compounds with $\mathbf{L}^{2}$ systematically failed, which evidences the different and particular coordinative preferences of both macrocyclic receptors towards copper(II) ion.

In the region $3500-3300 \mathrm{~cm}^{-1}$, the infrared spectra of complexes 1-4 (KBr discs) show a unique broad band corresponding to both $v_{\mathrm{as}}\left(\mathrm{NH}_{2}\right)$ and $v_{\mathrm{s}}\left(\mathrm{NH}_{2}\right)$ stretching frequencies of the coordinated amine groups. The absorption bands at approximately 1100 and 625 $\mathrm{cm}^{-1}$ present in the spectra of the perchlorate compounds ( 1 and 3$)$ assignable to the asymmetric $v_{\text {as }}(\mathrm{Cl}-$ O) stretching and $\delta_{\text {as }}(\mathrm{O}-\mathrm{Cl}-\mathrm{O})$ bending modes of the perchlorate group appear without splitting as befits an uncoordinated anion. The IR spectrum of compound $\mathbf{2}$ also displays a very intense band centred at $1380 \mathrm{~cm}^{-1}$ due to ionic nitrate groups. Together with this very intense band of the ionic nitrate now centred at 1384 $\mathrm{cm}^{-1}$, the IR spectrum of $\mathbf{4}$ also features bands at 1288 and $1475 \mathrm{~cm}^{-1}$ corresponding to coordinated nitrate [6].

The molar conductivities of the perchlorate complexes at $20^{\circ} \mathrm{C}$ in an approximately $10^{-3} \mathrm{M}$ acetonitrile solution were $\Lambda_{\mathrm{M}}=234 \mathrm{~cm}^{2} \Omega^{-1} \mathrm{~mol}^{-1}$ for 1 and 272 $\mathrm{cm}^{2} \Omega^{-1} \mathrm{~mol}^{-1}$ for 3 . These values reveal that both complexes behave as 2:1 electrolytes in this solvent and hence are completely dissociated [7]. Due to low solubility of the nitrate complexes in acetonitrile, their molar conductivities were measured in dimethylformamide under the same conditions. They show values of $\Lambda_{\mathrm{M}}=223 \mathrm{~cm}^{2} \Omega^{-1} \mathrm{~mol}^{-1}$ for 2 and $177 \mathrm{~cm}^{2} \Omega^{-1}$ $\mathrm{mol}^{-1}$ for 4 which are in the range reported for $2: 1$ electrolytes [7], indicating that these complexes are completely dissociated in DMF solution. The electronic spectra of complexes 1-4 were obtained in $\mathrm{CH}_{3} \mathrm{CN}$ solutions and exhibit a broad absorption in the visible with maximum at 795 (1), 750 (2), 750 (3) and $680 \mathrm{~nm}$ (4).

Recrystallisation of $\mathbf{1}$ in absolute ethanol gave green crystals suitable for X-ray crystallography. Table 2 summarises selected bonds and angles. Crystals of $\mathbf{1}$ contain the cation $\left[\mathrm{CuL}^{1}\right]^{2+}$ and two well separated perchlorate anions. Fig. 1 illustrates the structure of the cation. It contains a $\mathrm{CuN}_{4} \mathrm{O}_{3}$ core with the seven heteroatoms of $\mathbf{L}^{1}$ coordinated to the copper. The $\mathrm{Cu}(\mathrm{II})$ ion, with a small size $\left(r_{\mathrm{CN} 4}=0.57 ; r_{\mathrm{CN} 6}=0.73 \AA\right)$, resides in the macrocyclic cavity bound by the three ether oxygen atoms $[\mathrm{O}(1), \mathrm{O}(2)$ and $\mathrm{O}(3)]$ and the two pivotal amino nitrogen atoms $[\mathrm{N}(3)$ and $\mathrm{N}(4)]$. The donor atoms of the pendant arms $[\mathrm{N}(1)$ and $\mathrm{N}(2)]$ coordinate apically. The $\mathrm{N}(1)-\mathrm{Cu}-\mathrm{N}(2)$ angle has a value of $171^{\circ}$ and angles $\mathrm{O}(1)-\mathrm{Cu}-\mathrm{N}(3), \mathrm{N}(3)-\mathrm{Cu}-$ $\mathrm{O}(3), \mathrm{O}(3)-\mathrm{Cu}-\mathrm{N}(4), \mathrm{N}(4)-\mathrm{Cu}-\mathrm{O}(2)$ and $\mathrm{O}(2)-\mathrm{Cu}-$ $\mathrm{O}(1)$ take values very close to $72^{\circ}$. Thus, the coordination sphere of the copper ion can be described as a 
Table 2

Selected bond lengths $(\AA)$ and bond angles $\left(^{\circ}\right)$ for complex 1

\begin{tabular}{llll}
\hline Bond lengths & & & \\
$\mathrm{Cu}-\mathrm{N}(1)$ & $2.035(2)$ & $\mathrm{Cu}-\mathrm{N}(2)$ & $2.036(2)$ \\
$\mathrm{Cu}-\mathrm{N}(3)$ & $2.200(2)$ & $\mathrm{Cu}-\mathrm{N}(4)$ & $2.240(2)$ \\
$\mathrm{Cu}-\mathrm{O}(1)$ & $2.3788(17)$ & $\mathrm{Cu}-\mathrm{O}(2)$ & $2.4615(19)$ \\
$\mathrm{Cu}-\mathrm{O}(3)$ & $2.2173(18)$ & & \\
Bond angles & & & \\
$\mathrm{N}(1)-\mathrm{Cu}-\mathrm{N}(2)$ & $171.25(10)$ & $\mathrm{N}(1)-\mathrm{Cu}-\mathrm{N}(3)$ & $88.26(8)$ \\
$\mathrm{N}(2)-\mathrm{Cu}-\mathrm{N}(3)$ & $96.76(9)$ & $\mathrm{N}(1)-\mathrm{Cu}-\mathrm{O}(3)$ & $90.94(9)$ \\
$\mathrm{N}(2)-\mathrm{Cu}-\mathrm{O}(3)$ & $97.32(8)$ & $\mathrm{N}(3)-\mathrm{Cu}-\mathrm{O}(3)$ & $74.10(7)$ \\
$\mathrm{N}(1)-\mathrm{Cu}-\mathrm{N}(4)$ & $93.77(8)$ & $\mathrm{N}(2)-\mathrm{Cu}-\mathrm{N}(4)$ & $85.73(8)$ \\
$\mathrm{N}(3)-\mathrm{Cu}-\mathrm{N}(4)$ & $148.40(8)$ & $\mathrm{O}(3)-\mathrm{Cu}-\mathrm{N}(4)$ & $74.34(8)$ \\
$\mathrm{N}(1)-\mathrm{Cu}-\mathrm{O}(1)$ & $97.19(8)$ & $\mathrm{N}(2)-\mathrm{Cu}-\mathrm{O}(1)$ & $77.33(7)$ \\
$\mathrm{N}(3)-\mathrm{Cu}-\mathrm{O}(1)$ & $74.89(7)$ & $\mathrm{O}(3)-\mathrm{Cu}-\mathrm{O}(1)$ & $147.63(7)$ \\
$\mathrm{N}(4)-\mathrm{Cu}-\mathrm{O}(1)$ & $135.75(7)$ & $\mathrm{N}(1)-\mathrm{Cu}-\mathrm{O}(2)$ & 77.93 \\
$\mathrm{~N}(2)-\mathrm{Cu}-\mathrm{O}(2)$ & $93.53(8)$ & $\mathrm{N}(3)-\mathrm{Cu}-\mathrm{O}(2)$ & $136.09(7)$ \\
$\mathrm{O}(3)-\mathrm{Cu}-\mathrm{O}(2)$ & $146.28(7)$ & $\mathrm{N}(4)-\mathrm{Cu}-\mathrm{O}(2)$ & $74.76(7)$ \\
$\mathrm{O}(1)-\mathrm{Cu}-\mathrm{O}(2)$ & $66.00(6)$ & & \\
& & & \\
& & &
\end{tabular}

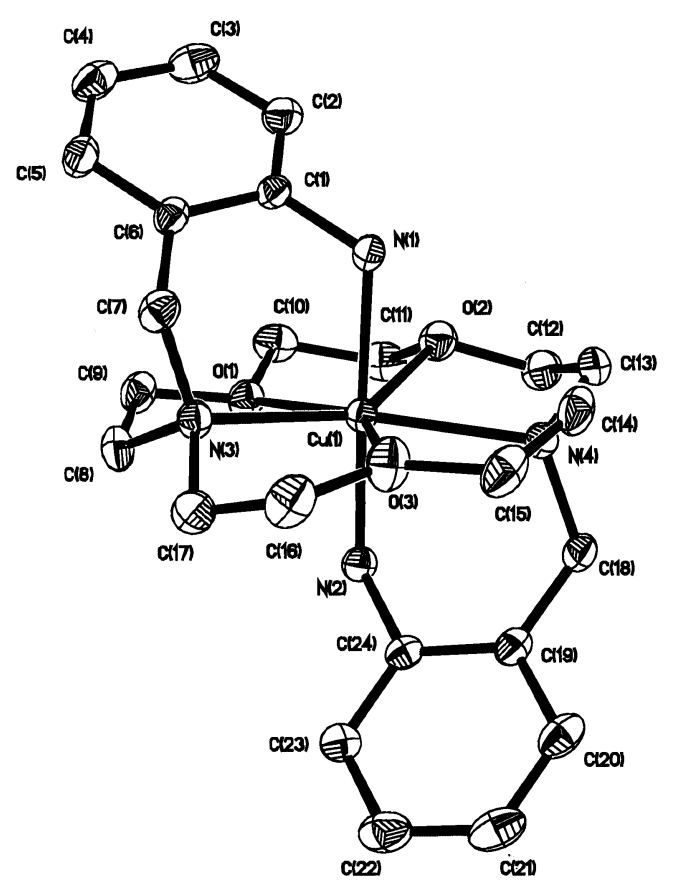

Fig. 1. X-ray crystal structure of the cation of $\mathbf{1}$ with atom labelling; hydrogen atoms are omitted for simplicity; the ORTEP plot is drawn at a $30 \%$ probability level.

distorted pentagonal bipyramid, as depicted in Fig. 2, with an axial compression, as the apical bonds $\mathrm{Cu}-$ $\mathrm{N}(1)$ and $\mathrm{Cu}-\mathrm{N}(2)$ are significantly shorter than the equatorial bonds. This figure also allows a clear appraisal of the distortion that is overall caused by an out-of-plane displacement of the ether oxygen atoms $\mathrm{O}(1)$ and $\mathrm{O}(2)$, which respectively lie $0.361 \AA$ beneath and $0.575 \AA$ above the plane formed by $\mathrm{Cu}, \mathrm{O}(3), \mathrm{N}(3)$ and $\mathrm{N}(4)$. Distances between $\mathrm{Cu}$ and both pivotal nitrogen atoms are slightly longer than those found in $N, N^{\prime}$-diacetato-1,10-diaza-15-crown-5 copper(II) [8], while distances between the metal ion and the oxygen atoms of the crown moiety are shorter.

In the cation $\left[\mathrm{CuL}^{1}\right]^{2+}$, the bibracchial lariat ether $\mathbf{L}^{1}$ shows an anti arrangement with both pendant arms disposed on opposite sides of the crown moiety. Although $\mathbf{L}^{1}$ also adopts an anti arrangement when it is fully uncoordinated [4], it feels largely the presence of a $\mathrm{Cu}(\mathrm{II})$ ion lodged into its cavity and so its fold is quite different in both cases. Particularly, it can be appreciated how the plane formed by the three oxygen atoms and one pivotal nitrogen atom when $\mathbf{L}^{1}$ is fully uncoordinated [4] disappears in the copper complex $\mathbf{1}$.

We have also obtained single crystals of $\mathbf{2}$ for X-ray analysis but they were not of the best quality, so that the structure refinement could not be completed. However, information on the $\mathrm{Cu}$ (II) environment is relatively accurate and these data show that the metal ion is also seven-coordinated with a distorted pentagonal bipyramidal geometry identical to the one present in $\mathbf{1}$. Distances between the copper and both apical nitrogen atoms, $\mathrm{N}(1)$ and $\mathrm{N}(2)$ are approximately $2.0 \AA$, while those between the copper and the equatorial donors are longer $(\mathrm{Cu}-\mathrm{N}$ (pivotal) approximately $2.3 \AA$; $\mathrm{Cu}-$ O(ether) approximately $2.2-2.3 \AA$ ), indicating also an axial compression.

\subsection{Copper complexes with $L^{3}$}

Reactions of $N, N^{\prime}$-bis(2-aminobenzyl)-4,13-diaza-18crown-6 $\left(\mathbf{L}^{2}\right)$ and salicylaldehyde in the presence of triethylamine and a copper(II) salt (perchlorate or nitrate) under the conditions described in Section 2 gave analytically pure products $\left[\mathrm{Cu}_{2}\left(\mathbf{L}^{3}-2 \mathrm{H}\right)\right]\left(\mathrm{ClO}_{4}\right)_{2} \cdot \mathrm{H}_{2} \mathrm{O}(\mathbf{5})$ and $\left[\mathrm{Cu}_{2}\left(\mathbf{L}^{3}-2 \mathrm{H}\right)\right]\left(\mathrm{NO}_{3}\right)_{2} \cdot \mathrm{H}_{2} \mathrm{O}(\mathbf{6})$, respectively, in $85 \%$

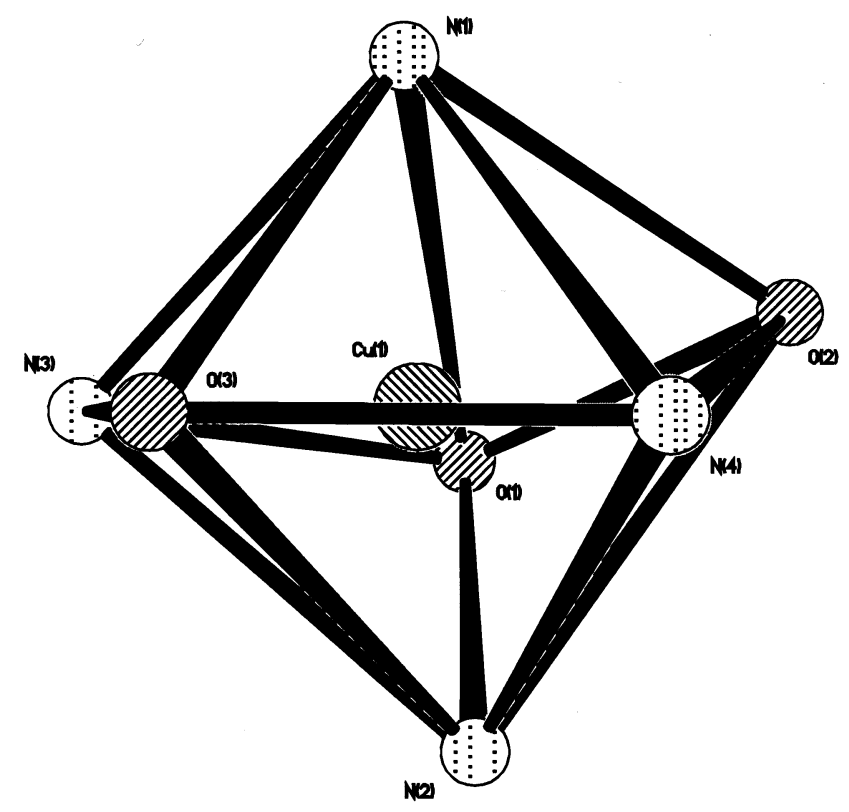

Fig. 2. Coordination polyhedron of the cationic complex $\left[\mathrm{CuL}^{1}\right]^{2+}$. 


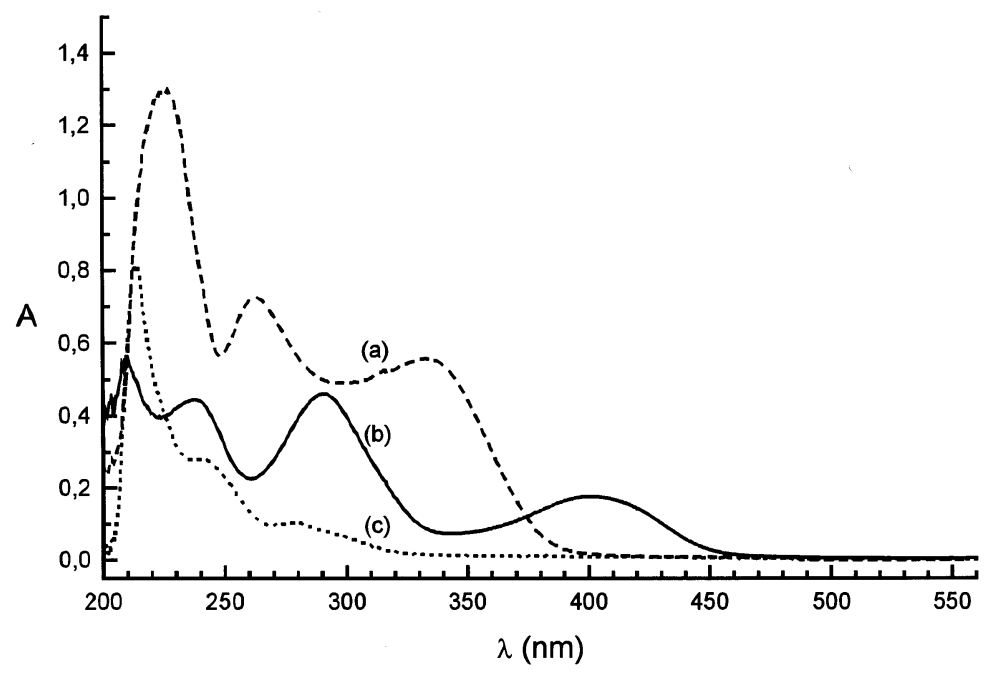

Fig. 3. UV spectra of (a) $\mathrm{L}^{3}$; (b) compound 5; (c) compound $\mathbf{5}$ upon reduction with $\mathrm{NaBH}_{4}$ in acetonitrile.

yield. The presence of a very intense absorption at 1608 $\mathrm{cm}^{-1}$, attributable to the $v(\mathrm{C}=\mathrm{N})_{\text {imine }}$ stretching mode in both infrared spectra ( $\mathrm{KBr}$ disks), as well as the absence of carbonyl and amine bands, confirm the Schiff-base formation. Comparison with the IR spectrum of the free ligand $\mathbf{L}^{3}$ shows that this band is shifted $10 \mathrm{~cm}^{-1}$ to lower wavenumber in the complexes. Bands due to the asymmetric stretching and bending modes of the perchlorate groups of $\mathbf{5}$ appear without splitting at 1100 and $625 \mathrm{~cm}^{-1}$, respectively, as expected for uncoordinated groups. The IR spectrum of 6 displays an intense band at $1385 \mathrm{~cm}^{-1}$ characteristic of ionic nitrate and no band due to coordinated nitrate has been observed. Parent-ion peaks in the FAB mass spectra are as expected for binuclear complexes. Peaks corresponding to the sequential loss of counterions are present at $m / z 905\left(5-\mathrm{ClO}_{4}\right), 806\left(5-2 \mathrm{ClO}_{4}\right), 868$ $\left(6-\mathrm{NO}_{3}\right)$ and $806\left(6-2 \mathrm{NO}_{3}\right)$.

Conductivity measurements on approximately $10^{-3}$ solutions of 5 in acetonitrile and $\mathbf{6}$ in DMF at $20^{\circ} \mathrm{C}$ led to values of $\Lambda_{\mathrm{M}}=276$ and $175 \mathrm{~cm}^{2} \Omega^{-1} \mathrm{~mol}^{-1}$, respectively, showing that both behave as $2: 1$ electrolytes in these solvents [7].

The UV-Vis spectrum of the free ligand $\mathbf{L}^{3}$ in acetonitrile solution features three absorption bands at $\lambda_{\max }=229,262$ and $334 \mathrm{~nm}$, corresponding to $\mathrm{E}_{1}, \mathrm{E}_{2}$ and $\mathrm{B}$ charge-transfer bands of the aromatic rings, respectively. The spectra of the complexes $\mathbf{5}$ and $\mathbf{6}$, besides these three expected bands, shifted to lower wavelength and appearing at 215, 238 and $290 \mathrm{~nm}$ for 5 and 218, 238 and 290 for 6, also display bands at 400 and $625 \mathrm{~nm}$ for 5 and 400 and $635 \mathrm{~nm}$ for $\mathbf{6}$. The band at $400 \mathrm{~nm}$ corresponds to a charge-transfer transition which involves the $\mathrm{Cu}$ (II) ion and both, the imine and phenolate groups of the macrocyclic receptor, as suggested by the fact that upon treating the solution of each particular complex with $\mathrm{NaBH}_{4}$ this band disap- pears (Fig. 3). The less intense band at approximately $630 \mathrm{~nm}$ is assigned to the expected $\mathrm{d}-\mathrm{d}$ transition for $\mathrm{Cu}(\mathrm{II})$ ion.

Green X-ray quality crystals of $\mathbf{5}$ were grown upon recrystallisation from acetonitrile. The crystal structure of $\mathbf{5}$ comprises a centrosymmetric dinuclear cation $\left[\mathrm{Cu}_{2}\left(\mathrm{~L}^{3}-2 \mathrm{H}\right)\right]^{2+}$ (half of the cation per asymmetric unit) and two independent perchlorate anions. Fig. 4 shows a view of the structure of the cationic complex, while selected bond lengths and angles are given in Table 3. Both $\mathrm{Cu}$ (II) ions have crystallographically identical co-

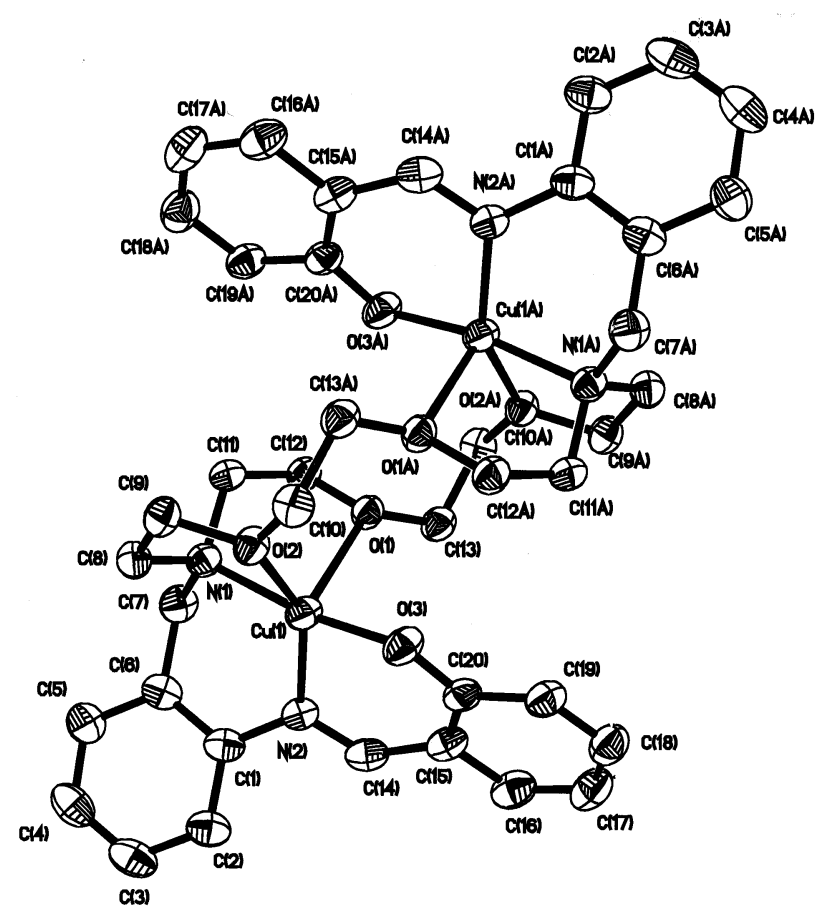

Fig. 4. X-ray crystal structure of the cation of $\mathbf{5}$ with atom labelling; hydrogen atoms are omitted for simplicity; the ORTEP plot is drawn at a $30 \%$ probability level. 
Table 3

Selected bond lengths $(\AA)$ and bond angles $\left(^{\circ}\right)$ for complex 5

\begin{tabular}{llll}
\hline $\begin{array}{l}\text { Bond lengths } \\
\mathrm{Cu}-\mathrm{N}(1)\end{array}$ & $2.008(4)$ & $\mathrm{Cu}-\mathrm{N}(2)$ & $1.973(4)$ \\
$\mathrm{Cu}-\mathrm{O}(1)$ & $2.359(3)$ & $\mathrm{Cu}-\mathrm{O}(2)$ & $2.105(3)$ \\
$\mathrm{Cu}-\mathrm{O}(3)$ & $1.872(4)$ & & \\
Bond angles & & & \\
$\mathrm{O}(3)-\mathrm{Cu}-\mathrm{N}(2)$ & $94.27(17)$ & $\mathrm{O}(3)-\mathrm{Cu}-\mathrm{N}(1)$ & $169.88(17)$ \\
$\mathrm{N}(2)-\mathrm{Cu}-\mathrm{N}(1)$ & $95.76(18)$ & $\mathrm{O}(3)-\mathrm{Cu}-\mathrm{O}(2)$ & $92.56(15)$ \\
$\mathrm{N}(2)-\mathrm{Cu}-\mathrm{O}(2)$ & $145.94(17)$ & $\mathrm{N}(1)-\mathrm{Cu}-\mathrm{O}(2)$ & $79.83(15)$ \\
$\mathrm{O}(3)-\mathrm{Cu}-\mathrm{O}(1)$ & $95.96(15)$ & $\mathrm{N}(2)-\mathrm{Cu}-\mathrm{O}(1)$ & $107.34(15)$ \\
$\mathrm{N}(1)-\mathrm{Cu}-\mathrm{O}(1)$ & $79.78(15)$ & $\mathrm{O}(2)-\mathrm{Cu}-\mathrm{O}(1)$ & $105.06(13)$ \\
\hline
\end{tabular}

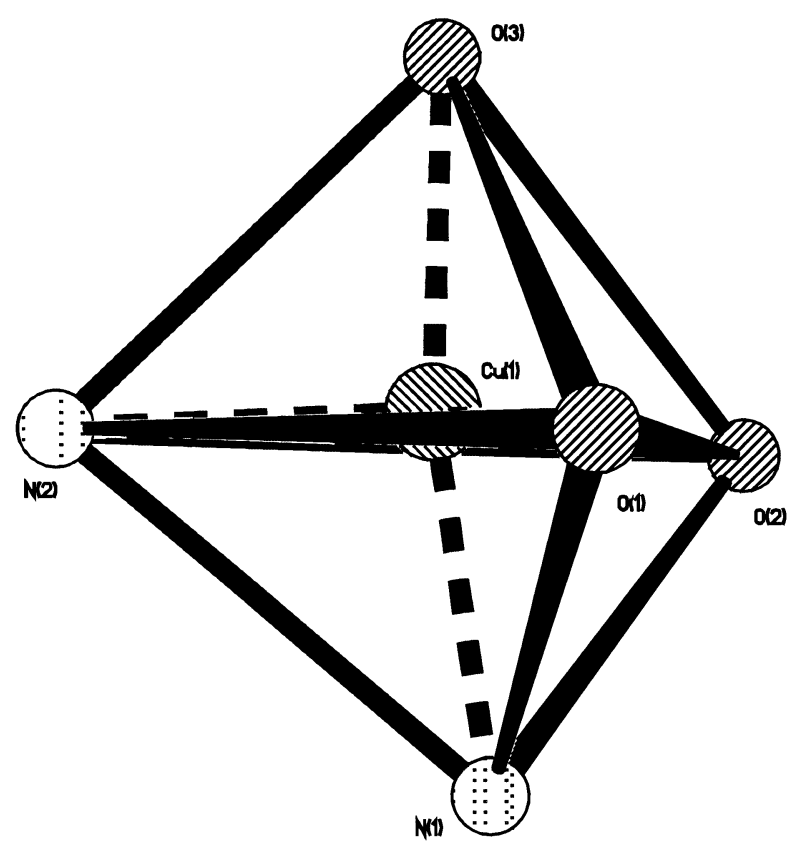

Fig. 5. Coordination polyhedron of each $\mathrm{Cu}(\mathrm{II})$ ion in the cationic complex $\left[\mathrm{Cu}_{2}\left(\mathrm{~L}^{3}-2 \mathrm{H}\right)\right]^{2+}$.

ordination environments; each is placed out of the crown hole but efficiently encapsulated by each pendant arm, being five-coordinated bound to one pivotal nitrogen atom $\mathrm{N}(1)$, one phenolate oxygen atom $\mathrm{O}(3)$, one imine nitrogen atom $\mathrm{N}(2)$, and two ether oxygen atoms, $\mathrm{O}(1)$ and $\mathrm{O}(2)$ and. Each $\mathrm{Cu}(\mathrm{II})$ ion, the two ether oxygen atoms and the imine nitrogen atom of its coordination sphere are essentially coplanar, with a deviation from planarity of just $0.0536 \AA$. This may be viewed as an equatorial plane with the pivotal nitrogen and phenolate oxygen atoms located 1.863 and 1.0768 $\AA$ above and beneath it, respectively. The coordination polyhedron around each metal ion could be described as a distorted trigonal bipyramid as shown in Fig. 5. In a five-coordinate geometry as depicted in Chart 2, perfectly trigonal bipyramidal geometry is associated with $\alpha=180^{\circ}$ and $\beta=120^{\circ}$, whereas ideal square-pyramidal geometry does with $\alpha=\beta=180^{\circ}$, although in the real square-pyramidal systems $\mathrm{M}$ is almost always dis- placed out of the BCDE plane towards A and $\alpha=\beta<$ $180^{\circ}$. A square-pyramidal polyhedron is characterised by $(\beta-\alpha)=0^{\circ}$ and a bipyramidal trigonal one does by $(\beta-\alpha)=60^{\circ}$. Thus, for assessing the degree of trigonality in five-coordinate transition metal complexes the expression formulated by Addison et al. [9], $\tau=(\beta-$ $\alpha) / 60$, where $\tau$ is the index of trigonality within the structural continuum between ideal trigonal bipyramidal and square-pyramidal, is really useful. The limiting cases are $\tau=0$ for perfectly square-pyramidal geometry and $\tau=1$ for perfectly trigonal bipyramidal geometry. In our compound $\mathbf{5}$, the $\tau$ factor takes an intermediate value of 0.40 indicating a significant distortion away from square-pyramidal where $\mathrm{O}(1)$ would be at the apex and the base would be provided by the other four donor atoms, $\mathrm{O}(2), \mathrm{O}(3), \mathrm{N}(1)$ and $\mathrm{N}(2)$ (r.m.s. deviation from planarity of $0.3138 \AA$ ).
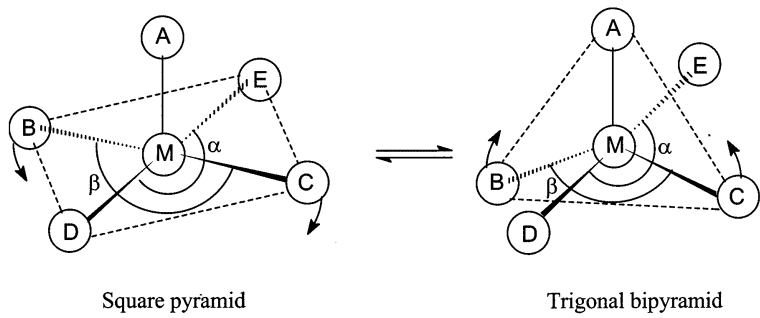

Chart 2.

Both pendant arms of the macrocyclic receptor are orientated on opposite sides resulting in an anti conformation. The angle between the planes defined by the aromatic rings of the same pendant arm takes a value of $54.5^{\circ}$. The distance between both pivotal nitrogen atoms has a value of $6.935 \AA$ while the distance between both imine nitrogen atoms is $8.643 \AA$. Both $\mathrm{Cu}$ (II) ions are $5.233 \AA$ far one from each other.

\subsection{EPR spectroscopy}

EPR spectra of complexes 1-6, dissolved in acetonitrile for 1, 3, 4 and 5, and ethanol for $\mathbf{2}$ and $\mathbf{6}$, have been recorded at 77 and $40 \mathrm{~K}$. The spectra obtained for complexes $\mathbf{1}$ and $\mathbf{5}$ were quite broad and featureless, and no spectral parameters could be obtained. The spectra corresponding to $\mathbf{2}$ and $\mathbf{6}$ are shown in Fig. 6. The spectrum of complex 2 (Fig. 6(a)) is very well defined having a rhombic spectrum atypical for monomeric copper complexes. The high rhombicity of the spectrum suggests a huge distortion of the copper site. Its spectral parameters, $g_{1}=2.273, g_{2}=2.14, g_{3}=$ 2.02, $A_{1}=97 \times 10^{-4} \mathrm{~cm}^{-1}, A_{2}=23 \times 10^{-4} \mathrm{~cm}^{-1}$ and $A_{3}=86 \times 10^{-4} \mathrm{~cm}^{-1}$ were obtained by spectral simulation. The crystal structure of the $\left[\mathrm{CuL}^{1}\right]^{2+}$ cation (complex 1, Fig. 2), shows a seven-coordinated $\mathrm{Cu}$ (II) $\left(\mathrm{CuN}_{4} \mathrm{O}_{3}\right)$ in a distorted pentagonal bipyramidal geometry. The bond distances (Table 2) show that the axial bonds of $\mathrm{Cu}$ (II) to the nitrogen atoms of the 
pendant arms, $\mathrm{N}(1)$ and $\mathrm{N}(2)$, are considerably shorter than the five equatorial bonds, leading to axial compression of the polyhedron. This polyhedron is also rhombically distorted because the two equatorial bonds to the pivotal amino nitrogen atoms $\mathrm{N}(3)$ and $\mathrm{N}(4)$ and to the ether $\mathrm{O}(3)$ atom are shorter than those to the other oxygens $\mathrm{O}(1)$ and $\mathrm{O}(2)$ and also because the $\mathrm{N}(1)-\mathrm{Cu}-\mathrm{N}(2)$ bond angle is significantly smaller than $180^{\circ}$. Therefore, this axially compressed, rhombically distorted geometry observed in the crystal structure leads us to consider a $\mathrm{d}_{z}^{2}$ ground state for the complex, which allows the assignment of $g_{1}, g_{2}$ and $g_{3}$ to $g_{x}, g_{y}$ and $g_{z}$, respectively $\left(g_{x}, g_{y}>g_{z} \sim 2\right)$ [10]. The EPR parameters for $\mathrm{Cu}(\mathrm{II})$ complexes are determined by the chemical composition and the geometry of the atoms nearest to the metal ion. The significant increase in the axial ligand field in this complex is most probably reflected in the measured values of the hyperfine coupling constants, which are much smaller than the values of $A_{\|}$found for six-coordinate complexes of distorted octahedral geometry, such as the bis(pyridine-2,6-diimine) $\mathrm{Cu}$ (II) complex $\left(A_{\|}=145 \times 10^{-4} \mathrm{~cm}^{-1}\right)$, with six nitrogen atoms in the coordination sphere [11], or the $[\mathrm{Cu}(\mathrm{NOTA})]^{-}$complex $(\mathrm{NOTA}=1,4,7$-triazacyclononane-1,4,7-triacetate $)\left(A_{\|}=149.5 \times 10^{-4} \mathrm{~cm}^{-1}\right)$, with three nitrogen and tree oxygen atoms in the coordination sphere [12].

The EPR spectra obtained for the binuclear complexes of $\mathbf{L}^{2}$ and $\mathbf{L}^{3}(\mathbf{3}, \mathbf{4}$ and $\mathbf{6})$ are much more complex, as exemplified by the nitrate salt of the com-

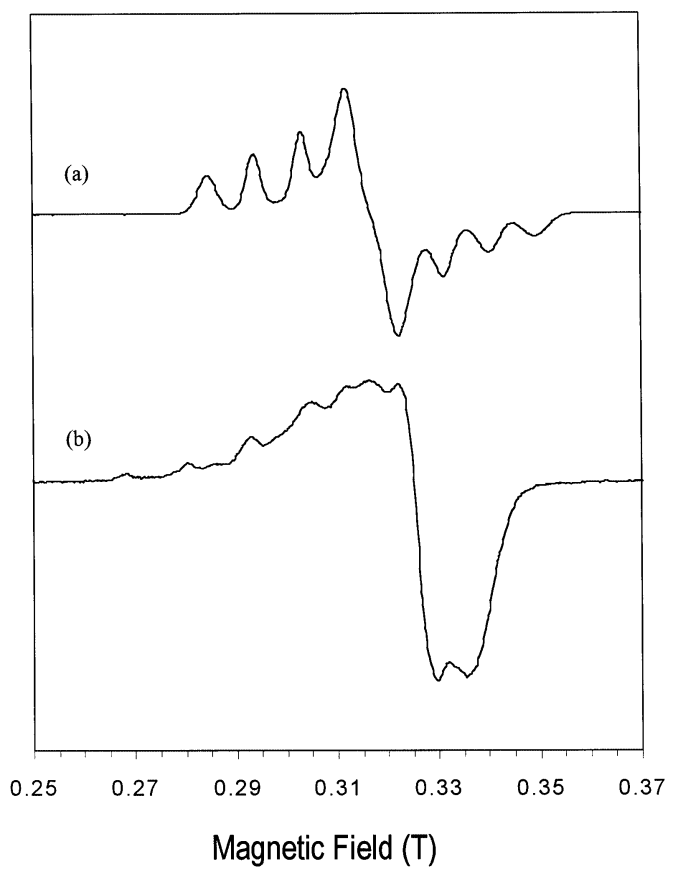

Fig. 6. EPR spectra (X-band, $0.34 \mathrm{~T}, 9.5 \mathrm{GHz}$ ), at $40 \mathrm{~K}$, of $0.5 \mathrm{mM}$ frozen solutions of the $\mathrm{Cu}$ (II) complexes $\left[\mathrm{CuL}^{1}\right]\left(\mathrm{NO}_{3}\right)_{2}$ (2) dissolved in acetonitrile (a) and $\left[\mathrm{Cu}_{2} \mathrm{~L}^{3}-2 \mathrm{H}\right]\left(\mathrm{NO}_{3}\right)_{2} \cdot \mathrm{H}_{2} \mathrm{O}(6)$ dissolved in ethanol (b). plex of $\mathbf{L}^{3}$ (complex $\mathbf{6}$ ) in ethanol glass at $40 \mathrm{~K}$ (Fig. 6(b)), and full spectral simulations could not be obtained. The EPR spectrum obtained for complex 6 shows at least seven peaks in the $g \|$ region, which result from intramolecular magnetic exchange interactions between the two $\mathrm{Cu}$ (II) ions in the binuclear complex, as found for outer-sphere $\mathrm{Cu}(\mathrm{II})$ dimers [13] or other binuclear $\mathrm{Cu}(\mathrm{II})$ complexes bridged by aromatic moieties $[14,15]$. We were unable to detect $\Delta M_{\mathrm{S}}=2$ EPR transitions expected for a $S^{\prime}=1$ dimer [13] in any of the dimeric complexes. This could result from their very low intensity found when the $\mathrm{Cu}-\mathrm{Cu}$ distance is larger than $5 \AA$, as found in the crystal structure of complex 5. In the case of axial symmetry, the parallel $\Delta M_{\mathrm{S}}=1$ transition of the dimer is expected to contain two sets (due to zero-field splitting) of seven copper hyperfine lines equally separated by $A_{\|}$, with spacing between the two sets equal to $2 D_{\|}$, where $D_{\|}$is the parallel component of the axial term of the zero-field splitting tensor $\mathbf{D}$ [16]. The dipolar zero-field interaction sharply decreases with increase of the $\mathrm{Cu}-\mathrm{Cu}$ distance $\mathrm{R}$, as shown by the equation $D_{\mathrm{dd}(\|)}=0.65 g_{\|}^{2} / R^{3}$ [17]. A spectral simulation of the $S^{\prime}=1$ coupled dimer, using the value of $D_{\|}=225.3 \times 10^{-4} \mathrm{~cm}^{-1}$ calculated from the value of $R=5.233 \AA$ for the crystal structure of complex $\mathbf{5}$, with $g_{\|}=2.20$ and $A_{\|}=74 \times 10^{-4} \mathrm{~cm}^{-1}$, shows that this value is much too large. As no structural data is available for complex 6, for which single-crystals for X-ray diffraction could not be obtained, we used the structural data available for the analogous complex $\mathbf{5}$ with perchlorate replacing nitrate as counterion. The low-field features of the experimental spectrum could be simulated by a much smaller value of $D_{\|}=23.4 \times 10^{-4}$ $\mathrm{cm}^{-1}$, together with $g_{\|}=2.20$ and $A_{\|}=115 \times 10^{-4}$ $\mathrm{cm}^{-1}$, except the fact the 'perpendicular' region could not be fitted properly. Thus, the present data does not allow any clear conclusion about magnetic coupling between the two $\mathrm{Cu}(\mathrm{II})$ centres in these binuclear complexes, which would require single crystal EPR data and temperature-dependent magnetic susceptibility measurements.

Assuming that magnetic coupling in the binuclear complexes is too small to be considered, the EPR spectrum of complex 6 (Fig. 6(b)) can be described by at least two well-defined axially symmetric components with hyperfine structure detected in the parallel region at low field, easily giving their $g_{\|}$and $A_{\|}$parameters. Thus, these correspond to $\mathrm{Cu}$ (II) species in a tetragonal ligand field with elongated axial bonds, giving a $\mathrm{d}_{x^{2}-y^{2}}$ ground state $\left(g_{\|} \gg g_{\perp}\right)$ [10]. This is in agreement with the crystal structure of $\mathbf{5}$, where each $\mathrm{Cu}$ (II) ion of the dinuclear species $\left[\mathrm{Cu}_{2}\left(\mathbf{L}^{3}-2 \mathrm{H}\right)\right]^{2+}$ is five coordinated in a distorted trigonal bipyramidal geometry (Fig. 5), containing the $\mathrm{CuN}_{2} \mathrm{O}_{3}$ atoms, and the bond distances shown in Table 3. One component of the spectrum of complex 6 has $g_{\|}=2.365$ and $A_{\|}=120 \times 10^{-4} \mathrm{~cm}^{-1}$, 
the other $g_{\|}=2.22$ and $A_{\|}=130 \times 10^{-4} \mathrm{~cm}^{-1}$. This fact suggests the presence of at least two different species in solution, probably due to the decomposition of $\mathbf{6}$ or interaction with the nitrate ion or the solvent ethanol molecule.

Both EPR spectra obtained for the perchlorate and nitrate salts of the binuclear complex of $\mathbf{L}^{2}$ (compounds 3 and $\mathbf{4}$, respectively), dissolved in acetonitrile, contain a major axially distorted component with tetragonal elongation, with $g_{\|}=2.36$ and $A_{\|}=143 \times 10^{-4} \mathrm{~cm}^{-1}$ for 3, and $g_{\|}=2.255$ and $A_{\|}=175 \times 10^{-4} \mathrm{~cm}^{-1}$ for 4 . Both spectra also contain an additional broad signal devoid of any hyperfine structure. This indicates that the coordination sphere of each of the two $\mathrm{Cu}$ (II) ions in the binuclear complex $\left[\mathrm{Cu}_{2} \mathrm{~L}^{2}\right]^{4+}$ can be expanded from four coordination by two nitrogen and two oxygen atoms of the ligand, including species which may bind the nitrate counterion and/or the co-crystallized ethanol molecule in the case of the nitrate salt.

\section{Concluding remarks}

We have studied the coordination properties of a structural series of bibracchial lariat ether towards copper(II) ion in the presence of two different counterions, perchlorate or nitrate. The lariat ethers, $N, N^{\prime}$-bis(2aminobenzyl)-1,10-diaza-15-crown-5 $\left(\mathbf{L}^{1}\right), \quad N, N^{\prime}$-bis(2aminobenzyl)-4,13-diaza-18-crown-6 $\left(\mathbf{L}^{2}\right)$ and $N, N^{\prime}-$ bis(2-salicylaldiminobenzyl)-4,13-diaza-18-crown-6 $\left(\mathbf{L}^{3}\right)$, this one in its deprotonated form, act as good receptors for the copper(II) ion. $\mathbf{L}^{1}$ is only able to form mononuclear complexes with it, but the incorporation of a $-\mathrm{CH}_{2}-\mathrm{O}-\mathrm{CH}_{2}-$ fragment into the shortest chain of the crown moiety of $\mathbf{L}^{1}$ gives rise to $\mathbf{L}^{2}$ which is now able to form binuclear complexes with $\mathrm{Cu}(\mathrm{II})$. The impossibility of preparing binuclear complexes with $\mathbf{L}^{1}$ and/or mononuclear compounds with $\mathbf{L}^{2}$ evidences the different coordinative properties of both receptors towards $\mathrm{Cu}(\mathrm{II})$. Condensation of salicylaldehyde and $\mathbf{L}^{2}$ leads to $\mathbf{L}^{3}$. When deprotonated, $\mathbf{L}^{3}$ also forms binuclear complexes with $\mathrm{Cu}(\mathrm{II})$, where each side arm is involved in the coordination of each metal ion and no donor atom act as a bridge between them. No clear evidence of magnetic coupling between the $\mathrm{Cu}$ (II) centres in the binuclear complexes could be obtained by $\mathrm{X}$-band EPR at $40 \mathrm{~K}$.

The nature of the counterion has no effect on the nuclearity of these complexes, the mono or binuclear structure being only determined by the number, nature and topology of the donor atoms of the lariat ether present. Moreover, the coordination polyhedron of complexes with $\mathbf{L}^{1}$ is also independent of the nature of the counterion, and identical in ethanolic solution and solid state, as deduced from both the X-ray structural analysis and the EPR spectroscopy.

\section{Supplementary material}

The crystallographic information files for the structures $\mathbf{1}$ and $\mathbf{5}$ are available from the authors upon request.

\section{Acknowledgements}

T.R.-B, A. de B., C.R.-I, D.E. and F.A. thank Xunta de Galicia (PGIDT00MAM10302PR) for financial support. D.E. also thanks Xunta de Galicia for a research grant. C.F.G.C.G. acknowledges financial support from Fundação para a Ciência e Tecnologia, Portugal (Praxis 2/2.1/SAU/1194/95).

\section{References}

[1] Y. Inoue, G.W. Gokel (Eds.), Cation Binding by Macrocycles, Marcel Dekker, New York, 1990.

[2] G.W. Gokel, Crown Ethers and Cryptands, The Royal Society of Chemistry, Cambridge, 1991.

[3] A. Kaifer, D.A. Gustowski, L. Echegoyen, V.J. Gatto, R.A. Schultz, T.P. Cleary, C.R. Morgan, D.M. Goli, A.M. Rios, G.W. Gokel, J. Am. Chem. Soc. 107 (1985) 1958.

[4] D. Esteban, D. Bañobre, A. de Blas, T. Rodríguez-Blas, R. Bastida, A. Macías, A. Rodríguez, D.E. Fenton, H. Adams, J. Mahía, Eur. J. Inorg. Chem. (2000) 1445.

[5] G.M. Sheldrick, SHelXtL, vol. 5, Siemens; Madison, WI, 1996.

[6] K. Nakamoto, Infrared and Raman Spectra of Inorganic and Coordination Compounds, 5th ed., Wiley, New York, 1997.

[7] W.J. Geary, Coord. Chem. Rev. 7 (1971) 81.

[8] (a) Z. Urbanczyk-Lipkowska, P. Gluzinski, J.W. Krajewski, R.A. Kolinski, J. Crystallogr. Spectrosc. Res. 19 (1989) 387. (b) R.E. Marsh, I. Bernal, Acta Crystallogr., Sect. B 51 (1995) 300.

[9] A.W. Addison, T. Nageswara-Rao, J. Reedijk, J. van Rijn, G.C. Verschoor, J. Chem. Soc., Dalton Trans. (1984) 1349.

[10] B.J. Hathaway, D.E. Billing, Coord. Chem. Rev. 5 (1970) 143.

[11] B. de Bruin, E. Bill, E. Bothe, T. Weyhermuller, K. Wieghardt, Inorg. Chem. 39 (2000) 2936.

[12] C.F.G.C. Geraldes, M.P.M. Marques, B. Castro, E. Pereira, Eur. J. Inorg. Chem. (2000) 559.

[13] D.M. Duggan, D.N. Hendrickson, Inorg. Chem. 13 (1974) 2929.

[14] E.F. Hasty, L.J. Wilson, D.N. Hendrickson, Inorg. Chem. 17 (1978) 1834.

[15] M.S. Haddad, D.N. Hendrickson, Inorg. Chem. 17 (1978) 2622.

[16] G.F. Kokoska, R.W. Duerst, Coord. Chem. Rev. 5 (1970) 209.

[17] K.W.H. Stevens, Proc. R. Soc. Lond., Ser. A 214 (1952) 237. 